\title{
METODE BERMAIN PERAN (ROLE PLAYING) UNTUK MENINGKATKAN HASIL BELAJAR SISWA PADA MATA PELAJARAN IPS
}

\author{
Oleh : Ari Yanto ) \\ Email : ari.thea86@gmail.com
}

\begin{abstract}
Abstrak
Salah satu masalah yang dihadapi oleh tenaga pengajar adalah masalah lemahnya proses pembelajaran. Dalam proses pembelajaran, siswa kurang didorong untuk mengembangkan kemampuan berfikir. Proses pembelajaran di kelas diarahkan kepada kemampuan siswa untuk menghafal informasi, otak siswa dipaksa untuk mengingat dan menimbun berbagai informasi tanpa dituntut memahami informasi yang diingat untuk dihubungkan dengan kehidupan sehari-hari. Oleh karena itu penting bagi guru untuk mengaplikasikan kegiatan pembelajaran yang menarik di kelas misalnya dengan cara menyapa siswa dengan ramah dan bersemangat, menciptakan suasana rileks, memotivasi siswa, dan menggunakan metode pembelajaran yang variatif.
\end{abstract}

Key words : Metode Bermain Peran (Role Playing), Hasil Belajar IPS

\section{Pendahuluan}

Dalam beberapa pengamatan secara langsung maupun tidak langsung terhadap proses pembelajaran yang berlangsung di Sekolah Dasar khususnya pembelajaran IPS, pembelajaran ini dirasakan sebagian besar siswa kurang memiliki daya tarik untuk dipelajari. Sehingga banyak siswa yang nilainya di bawah KKM. dalam pelaksanaan pembelajarannya juga tidak berjalan sebagaimana mestinya dan siswa cenderung lebih berminat terhadap pelajaran lain. Siswa dalam belajar cenderung merasa bosan, kurang tertarik, bahkan monoton atau berjalan seperti hari-hari biasa sebelumnya.

Latar belakang siswa merasa tidak tertarik dengan pelajaran IPS adalah pendidikan IPS merupakan mata pelajaran yang sangat luas dan didalamnya banyak terdapat materi berupa hafalan-hafalan, serta ruang lingkup yang dipelajarinya adalah manusia sebagai anggota masyarakat, gejala dan masalah social, dan peristiwa tentang kehidupan manusia yang terjadi di masyarakat. Selain itu, proses belajar mengajar di kelas yang bersifat konvensional sudah dianggap tidak relevan lagi dengan zaman sekarang, hal ini tidak melibatkan siswa secara langsung dalam pembelajaran sehingga siswa tidak mendapatkan kesan secara langsung dari pembelajaran tersebut. Fakta di lapangan adalah pada umumnya guru mengajarkan IPS secara verbal melalui kegiatan ceramah dan textbook oriented dengan keterlibatan siswa yang sangat minim, sehingga siswa hanya sebagai penerima informasi tanpa terlibat langsung dalam informasi tersebut.

Guna menyiasati pembelajaran IPS ini diperlukan kegiatan pembelajaran yang merangsang siswa menjadi aktif atau sering dikenal dengan istilah student centered. Peran guru bukan lagi pemberi informasi tetapi sebagai fasilitator dan organisator. Guru dalam melaksanakan pengelolaan pembelajaran hendaknya dilakukan dengan sungguh-sungguh melalui perencanaan yang matang, memanfaatkan seluruh sumber daya yang ada serta memperhatikan taraf perkembangan intelektual dan perkembangan psikologi belajar siswa. Guru yang demikian akan dapat menghasilkan kualitas pembelajaran yang lebih tinggi dibandingkan dengan guru yang dalam pengelolaan pembelajarannya dilakukan seadanya tanpa 
mempertimbangkan berbagai faktor yang bisa mempengaruhi keberhasilan proses pembelajaran. Dalam pembelajaran siswa dididik dan diarahkan agar dapat menemukan pengetahuan yang akan dipelajari secara tidak langsung. Dengan kata lain, tidak serta merta siswa diberi pengetahuan tentang fakta-fakta atau meteri pelajaran secara langsung, sehingga guru memberikan kesempatan kepada siswa untuk "merasakan" Ilmu Pengetahuan Sosial.

Selain itu, penggunaan metode pembelajaran dalam Kegiatan Belajar Mengajar (KBM) perlu dilakukan agar dapat menciptkan situasi belajar yang menumbuhkan stimulus bagi siswa untuk mengikuti pelajaran, tertarik pada kegiatan pembelajaran, tidak bosan terhadap KBM, dan kreatif dalam belajar, sehingga menghasilkan prestasi belajar yang baik pula.

\section{A. Metode Bermain Peran (Role Playing) Dalam Pembelajaran IPS}

Bermain peran (role playing) adalah cara menyajikan suatu bahan pelajaran atau materi pelajaran dengan mempertunjukkan, mempertontonkan, atau memperlihatkan suatu keadaan atau peristiwa-peristiwa yang dialami orang, cara atau tingkah laku dalam hubungan sosial. Jadi dengan kata lain bermain peran (role playing) adalah metode mengajar yang dalam pelaksanaannya peserta didik mendapat tugas dari guru untuk mendramatisasikan suatu situasi sosial yang mengandung suatu problem atau masalah, agar peserta didik dapat memecahkan suatu masalah yang muncul dari suatu situasi sosial tersebut (Mansyur, 1996:104).

Model pembelajaran bermain peran (role playing) merupakan bagian dari metode simulasi yang banyak digunakan dalam pembelajaran IPS karena metode-metode ini sangat sesuai dengan materi IPS dan kebutuhan perserta didik dalam proses pembelajaran yang berlangsung di kelas. Model ini juga sesuai dengan topik atau penyajian pembelajaran yang dekat dengan kehidupan anak pada umumnya, sehingga dalam pelaksanaannya anak akan mudah mengikuti pelajaran atau memerankan sesuatu yang diminta atau diperintah oleh guru yang sesuai dengan konsep atau materi pelajaran yang diajarkan.

Pengertian lain dari Model bermain peran (role playing) adalah sejenis permainan gerak yang di dalamnya terdapat tujuan, aturan, dan sekaligus melibatkan unsur menyenangkan (Jill Hahfiel, 1986; Wahab, 2000:111). Role playing sering kali dimaksudkan sebagai salah satu penerapan pengajaran berdasarkan pengalaman. Role playing dirancang untuk membantu siswa memperlajari nilai-nilai sosial yang mencerminkan dalam dirinya, menumbuhkan rasa empati terhadap orang lain, dan mencoba untuk mengembangkan keterampilan sosial. Maka dengan metode role playing siswa dapat menghayati peranan apa yang dimainkan, mampu menempatkan diri dalam situasi orang lain yang dikehendaki guru (Wahab, 2000:112).

Pada umumnya kebanyakkan siswa sekitar usia 9 tahun atau yang lebih tua, menyenangi penggunaan strategi ini karena berkenaan dengan isu-isu sosial dan kesempatan komunikasi interpersonal di dalam kelas. Di dalam bermain peran, guru menerima peran noninterpersonal didalam kelas, sedangkan siswa menerima karakter, perasaan, dan ide-ide orang lain dalam situasi yang khusus.

\section{Langkah-langkah Bermain Peran}

Dalam rangka menyiapkan suatu situasi bermain peran di dalam kelas, guru mengikuti langkah-langkah sebagai berikut :

a. Persiapan dan Instruksi

1) Guru memiliki situasi atau masalah bermain peran. Situasi-situasi yang dipilih harus menjadi "sosiodrama" yang menitik beratkan pada jenis peran, masalah dan situasi familier, serta pentingnya bagi siswa. Keseluruhan situasi harus dijelaskan, yang meliputi deskripsi tentang keadaan peristiwa, individu- 
individu yang dilibatkan, dan posisi-posisi dasar yang diambil oleh pelaku khusus. Para pemeran khusus tidak didasarkan pada individu nyata di dalam kelas, hindari tipe yang sama pada waktu merancang pemeran supaya tidak terjadi gangguan hak pribadi secara psikologis dan merasa aman.

2) Sebelum pelaksanaan bermain peran, siswa harus mengikuti latihan pemanasan, latihan-ltihan ini diikuti oleh semua siswa, baik sebagai partisipasi aktif maupun sebagai para pengamat aktif. Latihan ini dirancang untuk menyiapkan siswa, membantu mereka mengembangkan imajinasinya, dan untuk membentuk kekompakkan kelompok dan interaksi.

3) Guru memberikan instruksi khusus kepada peserta bermain peran setelah memberikan penjelasan pendahuluan kepada keseluruhan kelas. Penjelasan tersebut meliputi latar belakang dan karakterkarakter dasar melalui tulisan atau penjelasan lisan. Para peserta (pemeran) dipilih secara sukarela. Siswa diberi kebebasan untuk menggariskan suatu peran. Dalam brifing, kepada pemeran diberikan deskripsi secara rinci tentang kepribadian, perasaan, dan keyakinan dari para karakter. Dengan demikian dapat dirancang ruangan dan peralatan yang perlu digunakan dalam bermain peran tersebut.

4) Guru memberitahukan peran-peran yang akan dimainkan serta memberikan instruksi-instruksi yang bertalian dengan masing-masing peran kepada para audience. Para audience diupayakan mengambil bagian secara aktif dalam bermain peran itu. Untuk itu kelas dibagi dua kelompok, yakni kelompok pengamat dan kelompok spekulator, masing-masing melaksanakan fungsinya. Kelompok I bertindak sebagai pengamat yang bertugas mengamati : (1) persaan individu karakter, (2) karakter-karakter khusus yang diinginkan dalam situasi, dan (3) mengapa karakter merespons cara yang mereka lakukan. Kelompok II bertindak sebagai spekulator yang berupaya menanggapi bermain peran itu dari tujuan dan analisis pendapat. Tugas kelompok ini mengamati garis besar rangkaian tindakan yang telah dilakukan oleh pemeran.

b. Tindakan Dramatik dan Diskusi

1) Para aktor terus melakukan perannya sepanjang situasi bermain peran.

Sedangkan para audience berpartisipasi dalam penugasan awal kepada pemeran.

2) Bermian peran harus berhenti pada titiktitik penting atau apabila terdapat tingkah laku tertentu yang menuntut dihentikannya permainan tersebut.

3) Keseluruhan kelas selanjutnya berpartisipasi dalam diskusi yang terpusat pada situasi bermain peran. Masingmasing kelompok diberi kesempatan untuk menyampaikan hasil observasi dan reaksi-reaksinya. Para pemain juga dilibatkan dalam diskusi tersubut. Diskusi dibimbing oleh guru dengan maksud berkembang pemahaman tentang pelaksanaan bermain peran serta bermakna langsung bagi hidup siswa, yang pada gilirannya menumbuhkan pemahaman baru yang berguna untuk mengamati dan merespon situasi lainnya dalam kehidupan sehari-hari.

c. Evaluasi Bermain Peran

1) Siswa memberikan keterangan, baik secara tertulis maupun dalam kegiatan diskusi tentang keberhasilan dan hasilhasil yang dicapai dalam bermain peran. Siswa diperkenankan memberikan komentar evaluatif tentang bermain peran yang telah dilaksanakan, misalnya tentang makna bermain peran bagi meraka, caracara yang telah dilakukan selama bermain peran, dan cara-cara meningkatkan efektivitas bermain peran selanjutnya.

Guru menilai efektivitas dan keberhasilan bermian peran yang dilakukan siswa. Dalam melakukan evaluasi ini, guru dapat menggunakan komentar evaluasi dari siswa, catatan-catatan yang dibuat oleh guru selama berlangsungnya bermain peran. Berdasarkan evaluasi tersebut, selanjutnya 
guru dapat menentukan tingkat perkembangan pribadi, sosial, dan akademik para siswanya

Daftar centang ini berguna untuk menentukan prinsip-prinsip yang mendasari strategi bermain peran serta langkah-langkah yang perlu dilakukan agar pelaksanaannya dapat berhasil dan sesuai dengan apa yang diharapkan.

\section{Kelebihan Metode Bermain Peran (Role Playing}

Dalam metode bermian peran terdapat beberapa kelebihan, adapun kelebihan bermain peran antara lain :

a) Siswa melatih dirinya untuk melatih memahami dan mengingat bahan yang akan didramakan atau diperankan. Sebagai pemain harus memahami dan menghayati isi cerita secara keseluruhan, terutama untuk materi yang harus diperankannya. Dengan demikian daya ingat dan ketrampilan siswa akan terlatih.

b) Siswa akan terlatih untuk berinisiatif dan berkreatif. Pada waktu bermain siswa dituntut untuk mengemukakan pendapatnya sesuai dengan materi dan waktu yang tersedia.

c) Bakat yang terpendam pada diri siswa dapat dibina sehingga dimungkinkan akan muncul generasi seniman dari sekolah. Jika seni drama mereka dibina dengan baik kemungkinan besar mereka akan menjadi pemeran seni yang baik suatu saat.

d) Kerja sama antar pemain dapat ditumbuhkan dan dibina dengan sebaikbaiknya untuk mendidik siswa dalam menghargai karya atau hasil belajar siswa lain.

e) Siswa memperoleh pengalaman untuk menerima dan membagi tanggung jawab dengan sesamanya.

f) Bahasa lisan siswa dapat dibina menjadi bahasa yang baik agar mudah difahami orang lain.

\section{Kelemahan Metode Bermain Peran (Role Playing)}

Sedangkan kelemahan atau kekurangan dari metode bermain peran adalah sebagai berikut :

a) Sebagian besar anak yang tidak ikut bermain peran mereka menjadi kurang aktif.

b) Banyak memakan waktu, baik waktu persiapan dalam rangka pemahaman isi bahan pelajaran maupun pada pelaksanaan pertunjukkan.

c) Memerlukan tempat yang cukup luas, jika tempat bermain sempit menyebabkan gerak pemain kurang bebas.

d) Kelas lain sering terganggu oleh suara pemain dan para penonton yang kadangkadang bertepuk tangan dan sebagainya

\section{Cara Mengatasi Kelemahan- kelemahan Metode Bermain Peran}

Usaha-usaha untuk mengatasi kelemahan-kelemahan dari metode bermain peran (role playing), antara lain :

a) Guru harus menerangkan kepada siswa, untuk memperkenalkan metode ini, bahwa dengan jalan bermain peran (role playing) siswa diharapkan dapat memecahkan masalah hubungan sosial yang aktual ada di masyarakat atau sesuai dengan masalah yang terdapat dalam pelajaran yang sedang diajarkan oleh guru. Kemudian guru menunjuk beberapa siswa yang berperan, sedangkan siswa yang menjadi penonton dengan tugas-tugas tertentu pula.

b) Guru harus memilih masalah yang urgen sehingga menarik minat anak untuk mengikuti pembelajaran. Ia dapat menjelaskan dengan baik dan menarik, sehingga siswa terangsang untuk memecahkan masalah tersebut.

c) Agar siswa memahami peristiwanya, maka guru harus bisa menceritakan saat adegan berlangsung.

d) Bobot atau luasnya bahan pelajaran yang akan didramakan harus sesuai dengan waktu yang tersedia. Oleh karena itu, harus diusahakan agar para pemain 
berbicara dan melakukan gerakan sesuai dengan naskah cerita atau materi pelajaran dan tidak keluar dari peran yang didapatnya.

\section{B. Hasil Belajar IPS}

Kegiatan yang dilakukan oleh individu akan mengakibatkan perubahanperubahan baik berupa pengetahuan maupun sikap dan keterampilan. Perubahan itu adalah hasil yang telah dicapai dari proses belajar. Pengertian hasil belajar yang dikemukakan oleh Nana Sudjana, (2002:22) bahwa "Hasil belajar adalah kemampuan-kemampuan yang dimiliki siswa setelah menerima pengalaman belajarnya".

Pengertian lain tentang hasil belajar dikemukakan oleh Howard dalam Nana Sudjana, (2002:22) : Hasil belajar dibagi menjadi tiga macam, yakni (a) keterampilan dan kebiasaan, (b) pengetahuan dan pengertian, (c) sikap dan cita-cita, masingmasing jenis hasil belajar dapat diisi dengan bahan pelajaran yang telah ditetapkan dalam kurikulum. Hasil belajar adalah pola-pola perbuatan, nilai-nilai, pengertian, sikapsikap, apresiasi, abilitas, dan keterampilan (Hamalik, 2001:31). Siswa memperoleh informasi dan adanya perubahan dan peningkatan dari segi afektif, kognitif, dan psikomotor dari sebuah pembelajaran yang dilakukan oleh seorang pendidik.

Pengertian hasil belajar tersebut dapat disimpulkan bahwa hasil belajar merupakan perubahan perilaku akibat dari proses belajar mengajar. Hasil belajar dapat diukur melalui kegiatan penilaian. Penilaian dapat diartikan sebagai suatu tindakan atau kegiatan untuk menilai sejauh mana tujuan-tujuan instruksional tercapai atau sejauh mana materi yang diberikan dapat dikuasai oleh siswa. Hasil belajar dapat dilaporkan dalam bentuk nilai atau angka.

\section{Penutup}

Para guru hendaknya menyadari bahwa pembelajaran yang menggunakan Metode Bermain Peran (Role Playing) dapat meningkatkan hasil belajar siswa. Oleh karena itu, guru hendaknya dapat menggunakan Metode Bermain Peran (Role Playing) setiap proses pembelajaran.

Dalam konteks Metode Bermain Peran (Role Playing) guru dituntut tidak hanya memerankan diri sebagai pengajar atau pendidik, tetapi juga sebagai fasilitator dan motivator bagi peserta didik.

\section{DAFTAR PUSTAKA}

Hamalik, Oemar. 1999. Proses Belajar Mengajar Kooperatif. Jakarta : Bumi Aksara.

Hamalik, Oemar. 2003. Kurikulum dan Pembelajaran. Jakarta : Bumi Aksara.

Sudjana, Nana dan Ibrahim. 1989. Penelitian dan Penilaian Pendidikan. Bandung : Sinar Baru.

Wahab, A. 1998. Metodologi Pengajaran IPS. Jakarta : Karunia 